\title{
Performance Evaluation of Pneumatic Dryer for Aren (Arenga piñata) Flour
}

\author{
Suherman Suherman ${ }^{l}$, and Nur Hidayati $^{2}$ \\ ${ }^{1}$ Chemical Engineering Department, 50275 Diponegoro University, Indonesia \\ ${ }^{2}$ Master of Chemical Engineering, 50275 Diponegoro University, Indonesia
}

\begin{abstract}
Aren (Arenga pinata) tree is one type of palm plant that produces fruit, sap and starch or flour in the trunk. Industries aren flour usually in small and medium industries is dried by conventional method with dried under the sun. The main constraint is the low drying speed. Therefore, in this study aren flour with a water content of $40 \%$ was dried using a pneumatic dryer to moisture content below $15 \%$ (wet base). The aim of this research is to analyze the influence of drying air temperature, drying air flow rate and feeding speed to drying speed and energy analysis. Energy analysis was performed to determine the performance of pneumatic dryers. The energy analysis itself is done in the form of energy utilization and energy efficiency. The results show that the increase of dryer temperature from 60 to 100 will increase the utilization of energy from 0.61 to $1.39 \mathrm{~J} / \mathrm{s}$, energy efficiency is $33.4-45.1 \%$. the results of a proximate analysis, an ash content of 0.39 grain fiber 0.18 white degree $92.93 \%$ which already fulfill SNI standard of Aren flour.
\end{abstract}

\section{Introduction}

Aren tree is one type of palm plant. All parts of the tree can be used and have economic value. starting from the physical parts (roots, trunk, leaves, fibers etc.) as well as the results of its production (nira, flour and fruit). Aren including Aracaceae tribe (aracea nut). The tree is not spiny, unbranched, the height can reach 25 meters and the diameter of the tree can reach $65 \mathrm{~cm}[1]$.

This plant is almost similar to the coconut tree. Coconut tree trunked clean with old leaves that easily loose, aren tree trunk is very dirty because the stems are clad in fibers, so that the old leaves bark is difficult to be taken or out of the stem. Therefore, aren tree trunks are often overgrown by many types of ferns [1].

Empulur stem aren powder $48.9 \%$. However, each aren tree produces varied flour. In Indonesia from every aren tree trunk can be obtained flour between $60-70 \mathrm{~kg}$. aren flour is widely used for foodstuffs such as cakes, cendol, meatballs, noodles, vermicelli and hun kwe [2]. The standard quality of aren flour in Indonesia is contained in the Indonesian National Standard SNI 01 3724 - 1995. In the production process of aren flour, one of the important stages is the drying the product [3].

The pneumatic dryer is one of the mechanical drying machines that utilizes high-speed air and high temperature. The use of high-speed air and high temperature will cause the product to dry in a short time. The pneumatic dryer includes continuous dryer with a granule solid feed $[4,5]$. The solids are driven to duct drying by the hot air produced by the heater with the air from the blower and then the product passed to the cyclone. this type of dryer can be used for granular materials and non-abrasive solids[6].

Pneumatics can also produce a particle size reduction (friction) because the feeder is a screw conveyor. Pneumatic dryers are also particularly suitable for heat sensitive, explosive, degradable or flammable materials processing, otherwise the average residence time of solids is relatively short (usually a few seconds) [7].

Drying is a process of evaporation of moisture content in materials involving heat and mass transfer between the surface of the product and the environment $[8,9]$. Drying is widely used in various thermal applications such as food, perennial products and other industrial products [10] The purpose of drying is to degrade the moisture content in the solid can be removed by evaporation. In addition to extending shelf life as well to simplify storage simplify as well as in material transport $[11,12]$.

Research on batch drying system has been done [13], [14] while continuous drier still little information. Energy analysis can be interpreted as a calculation of the flow of energy in a production process, usually for the process to be economical. Energy analysis is based on the first law of thermodynamics[15]. where the first thermodynamic law assumes that energy cannot be created and destroyed so that all incoming energy will be converted into other forms of energy [16].

Some researchers have conducted energy analysis on drying, especially on food products and agricultural products, among others, potatoes drying [11], olive drying [13], drying of palm cocoa [14], carrots drying [8] Mulberry drying [16], beans and nuts drying [17], wheat drying [18], and drying of seaweed [19].

Corresponding author: suherman.mz@che.undip.ac.id 
Information on energy analysis on food drying has been widely described, but the use of energy analysis in continuous system drying is rare.

Energy analysis is a calculation on systems that consume energy that aims to know the balance of energy use, energy conversion equipment efficiency, specific energy consumption [20]. The aims of this study are the experimental research on the drying of aren flour in a pneumatic dryer, to know the performance of the aren flour drying tool by calculating the energy analysis. Energy efficiency calculations can be used to evaluate the performance of a drying machine.

\section{Materials and Methods}

\subsection{Materials}

Material used in this experiment were Aren flour, which taken from Klaten, Central Java. The equipment used in this experiment are Pneumatic dryer, moisture keet meter, humidity meter, oven, digital scales, porcelain cup, and anemometer. Drying time is 60 minutes for each variable with moisture content measured every 5 minutes. Two hundreds grams of Aren flour were used on each variables. The variabels were drying temperature $\left(60,70,80,90\right.$ and $\left.100^{\circ} \mathrm{C}\right)$, feed flow rates $(10,20$ and 30 gram/minutes) and air flow rate $(2,8 ; 3,7 ; 4,1 ;$ and 5,1 $\mathrm{m} / \mathrm{s}$ )

\subsection{Drying Equipment}

Pneumatic consists of temperature controller, blower, heater, feeder, screw conveyor, duct dryer, cyclone and output product. The Pneumatic dryer must be calibrated first before the drying process. The calibration is done by turning on the dryer and measure the temperature and the air flow rate for 1 minute until constant value

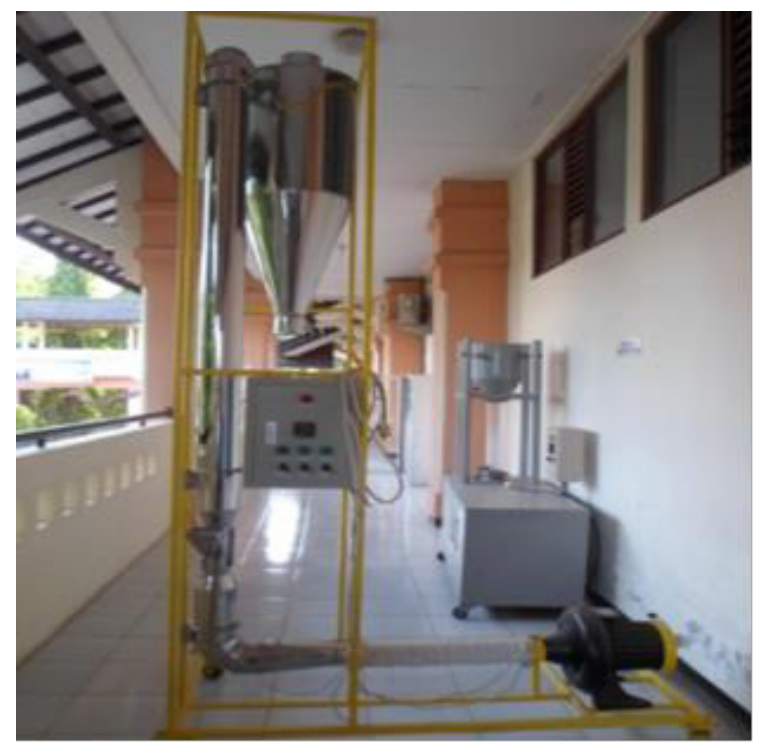

Fig. 1. Pneumatic dryer.

\subsection{Research Procedure}

The solid feed flow rate of $10 \mathrm{~g} /$ minute is calculated manually and continuously by introducing a certain amount of flour mass by weight and increments gradually over a predetermined time. The drying process was carried out by varying the dryer air temperature is $60,70,8090$ and $100^{\circ} \mathrm{C}$. Raw materials enter through the feeder and then forwarded to the duct dryer Aren flour. Before the experiment began, air temperature and air flow rate set first. After turning on the blower, then set the desired temperature. Wait a while until the air dryer from the blower reaches the desired temperature. Feed aren flour is inserted after the condition of the dryer is constant. The feed from the feeder will be pushed upward through a cylindrical drying tube with a total length of $170 \mathrm{~cm}$ and an inner diameter of $12 \mathrm{~cm}$. During drying, the feeder continuously feeds the wet aren flour into the drying duct. Out of the drying duct, the dry aren flour will be passed to the cyclone to separate the solid from hot air. Furthermore, dried aren flour was collected for product analysis

\subsection{Calculation of Dryer Efficiency}

The energy analysis method follows the formula derived by [21]. EU (Energy Utilization) can be known by applying the first thermodynamics law

$$
E U=M a(h a i-h a o)
$$

Where hai is the air dryer enthalpy at the inlet temperature $(\mathrm{J} / \mathrm{kg})$ and hao is the air dryer enthalpy at the exit temperature $(\mathrm{J} / \mathrm{kg})$ and the EU is Energy Utilization $(\mathrm{J} / \mathrm{s})$. The mass flow rate can be calculated using the equation

$$
M a=\rho a V a
$$

Where $\rho \mathrm{a}$ is the density of dry air in $\mathrm{kg} / \mathrm{m}^{3}, \mathrm{Va}$ is the volumetric air dryer rate in $\mathrm{m}^{3} / \mathrm{s}$. The drier air enthalpy at the entry and exit temperature of hi and ho can be calculated by the equation equation

$$
h=C p a T d a+W h s a t
$$

Where Cpa is the specific heat of dry air in $\mathrm{J} /\left(\mathrm{kg}^{\circ} \mathrm{C}\right), \mathrm{T}$ is the drying air temperature in ${ }^{\circ} \mathrm{C}, \mathrm{W}$ is the ratio of the drying air humidity $\left(\mathrm{kg} \mathrm{H}_{2} \mathrm{O} / \mathrm{kg}\right.$ da) and is the drying air and hsat is the saturated vapor enthalpy in $\mathrm{J} / \mathrm{kg}$ The specific heat of the dryer air can be calculated by the equation

$$
C p a=1.0029+5.4 \times 10-5 T d a
$$

The ratio of energy utility can be calculated using equation

$$
E U R=(M a(h a i-h a o)) /(M a(h a i-h a \alpha))
$$

Where EUR is the ratio of energy utilization and ha $\alpha$ is the air dryer enthalpy of environmental temperature $(\mathrm{J} / \mathrm{kg})$. The energy efficiency (\%) can be evaluated and the ratio of energy used to the given energy 


$$
\eta E=[(E i-E o) / E i] * 100
$$

$\eta \mathrm{E}$ is the energy efficiency, $\mathrm{E} i$ is the incoming energy and Eo is the out energy, where

$$
\begin{aligned}
& E i-E o=M a(\text { hai-hao }) \\
& E i=M a * h a i
\end{aligned}
$$

\section{Results and Discussion}

\subsection{Effect of temperature on the drying curve}

The drying air temperature is defined as the mean air temperature used to dry the amount of material measured in the drying chamber [15]. During the drying process, the temperature very important in the evaporation process of water, whether on the surface of the material or inside the material. The dryer air temperature should be adjusted so that the dried material can be as dry as possible so that it meets the SNI standard for acceptance in the market. The drying curve shows changes in the water content in the aren flour throughout the drying chamber under different drying conditions. In the experiment, the operating temperature of the dryer air was varied at $60,70,80,90$, and $100^{\circ} \mathrm{C}$. Within every 5 minutes it measures the moisture content along the dryer duct

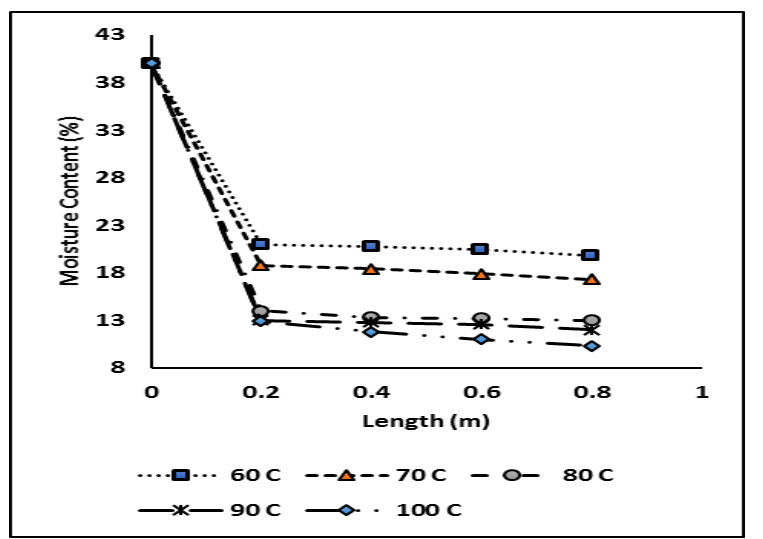

Fig. 2. Effect of dryer air temperature on the moisture content profile of aren flour each the dryer duct $(10 \mathrm{~g} / \mathrm{min})$.

The average initial moisture content of wet aren before being put into a pneumatic dryer is $40 \%$. The influence of drying air temperature along the drying chamber to the Aren drying curve is shown in Fig 2. The results show that there is a decrease in the drying curve along the drying duct (0.2 - $0.8 \mathrm{~m} /$ length) at each drying air temperature. The water content of aren flour at each temperature decreased a significant curve at $0.2 \mathrm{~m} \mathrm{duct}$ until constant drying occurred on duct $0.8 \mathrm{~m}$. The decrease occurred at $19.8 \%$ at $60^{\circ} \mathrm{C}$, while at $70,80,90$ and $100^{\circ} \mathrm{C}$, the water content decreased to $17.3 \%, 13 \%$, $12 \%$ and $10.3 \%$. The drying curve shows a decrease in the water content of aren flour along with the dryer duct until the small decrease is almost constant, the solid feed flow rate is $10 \mathrm{~g} / \mathrm{min}$ and the inlet airflow rate of 0.25 is due to the larger drying air temperature, water in the product. This result is in accordance with previous study which in drying tapioca by means of a continuously fluidized bed fluidization dryer at a drying distance divided into 3 zones of decreasing moisture content throughout the zone and at the drying effected in cassava starch[20,21].

\subsection{Effect of air flow rate}

Air flow rate is an important factor to be considered in drying by using pneumatic dryers. In this study, variations were made to the air velocity of the dryer as a heat carrier medium. Air velocity variation is carried out by arranging the air inlet opening a blower, is by using a cover plate with 4 openings variation is openings 0.25 $(2.8 \mathrm{~m} / \mathrm{s}) 0.5(3.7 \mathrm{~m} / \mathrm{s}), 0.75(4.1 \mathrm{~m} / \mathrm{s})$ and $1(5.1 \mathrm{~m} / \mathrm{s})$

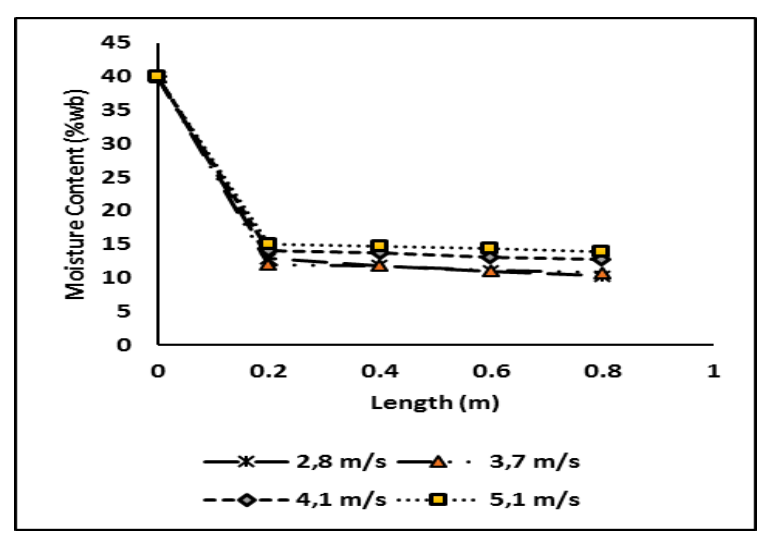

Fig. 3. Effect of air drying inlet openings on the moisture content profile of aren flour along the dryer duct ( $10 \mathrm{~g} / \mathrm{min})$

The determination of the air velocity to be used to dry a material must be observed. The larger the air inlet opening, the air velocity exhaled by the blower will be higher. To achieve an efficient drying process, the dryer airflow rate used should be greater than the minimum speed required to remove the material. The air velocity exhaled by the blower must be greater than the free fall velocity of the particles to be dried (wet material). The results showed that with the higher air velocity, the water content in solids is also higher. The solid water content at $2.8 \mathrm{~m} / \mathrm{s}$ is $10.3 \%$, at a speed of $3.7 \mathrm{~m} / \mathrm{s}$ is $10.8 \%$, at a speed of 4.1 is $13 \%$ and at a speed of $5.1 \mathrm{~m} / \mathrm{s}$ is $14.4 \%$. The speed of air flow during the drying process by using pneumatic (flash) dryer at a very low speed, the material particles cannot be lifted by the air flow, so the drying process cannot run perfectly. While the flow of air velocity is too high will cause the heat contact between dry air with the material will become too short, consequently the drying process becomes ineffective, because the water is vaporized only slightly, and the final water content of the product is usually still higher, this is in accordance with previous research on drying cassava with pneumatic dryer that the higher the rate of air flow rate then the moisture content is getting bigger, 
this is because the contact between the hot air and the solid becomes shorter so that drying is not optimal [22].

\subsection{Effect of feed flow rate}

Aren drying research is implementing a continuous system. Aren Flour with water content $\pm 40 \%$ is feed continuously into the dryer. The flow rate of sugar palm is varied by $10 \mathrm{gr} / \mathrm{min}, 20 \mathrm{gr} / \mathrm{min}$ and $30 \mathrm{gr} / \mathrm{min}$

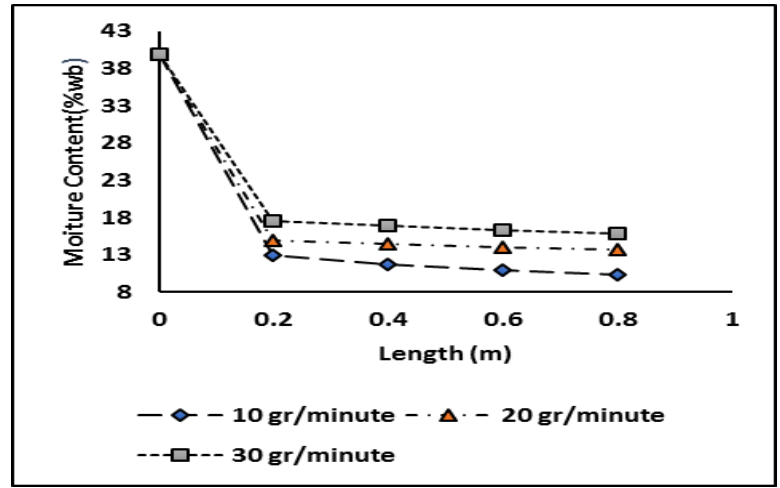

Fig. 4. Effect of solid feed flow rate on the water content profile of the material along the dryer $\operatorname{duct}\left(100^{\circ} \mathrm{C}\right)$.

The drying curve indicates that the Aren feed incorporated every minute in the pneumatic drying apparatus may affect the change in moisture content along the drying duct in the dry palm sugar product. Fig 4 shows that more aren flour is fed to the dryer, causing a decrease in water content longer to reach a constant. This is due to the faster saturation of dryer air. More moisture content material makes the dryer air faster saturated with the same air dryer capacity. This saturation will make the air dryer longer to remove the water content in aren flour. This trend is similar to the results in study monitoring and control of fluid-bed drying of tea where feed flow rate control is necessary to regulate the final moisture content of the product [23]

\subsection{Volumetric water evaporation rate}

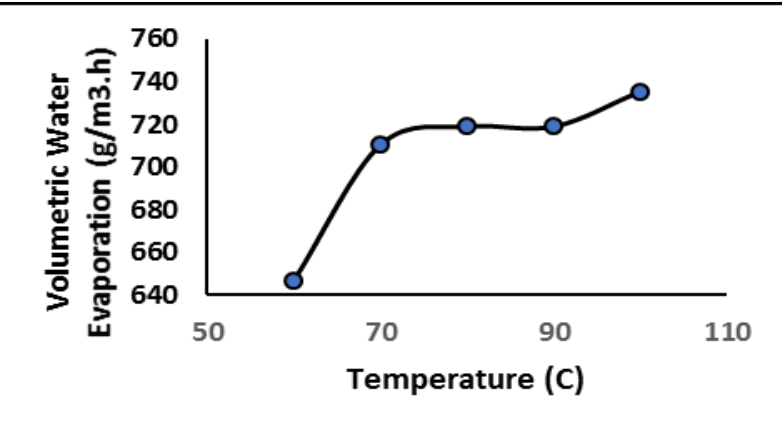

Fig. 5. Effect of temperature on volumetric water evaporation rate.
The rate of volumetric water evaporation increase with increasing air temperatures because higher air temperatures lead to greater differences between air temperature and starch surface temperature, which is the driving force for heat transfer[24]. Changes in air temperatures lead to changes in clearer moisture levels, increased feed flow rates at constant temperature causing a volumetric increase in the rate of water evaporation. Despite using a lower drying temperature, the moisture obtained by using a pneumatic dryer system is considerable

\subsection{Energy Utilization}

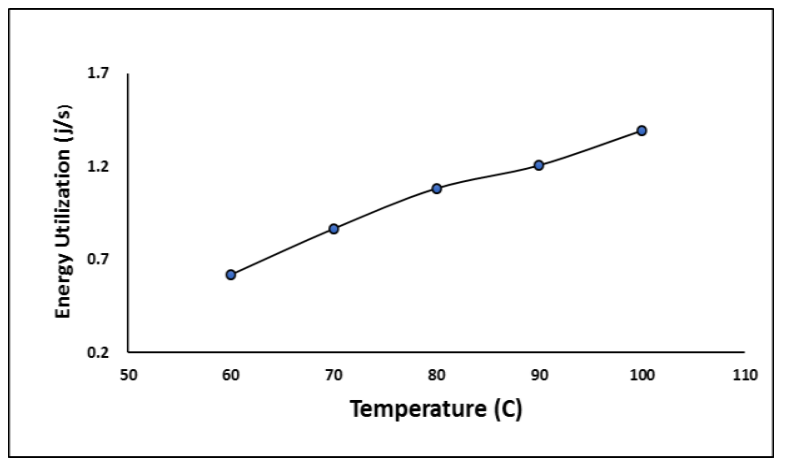

Fig. 6. Effect of dryer air temperature on energy utilization of Aren flour

Energy analysis uses the data obtained from the experiment. The images show the effect of temperature on energy utilization where energy use increase with increasing drying air temperature in pneumatic dryer. The higher the temperature causes a lot of moisture content to be evaporated. This is due to the high temperatures causing heat transfer and also the higher the period to increase the use of energy in reducing the product water content, obtained the average of energy usage at 60-100 $\mathrm{C}$ temperature variation increased from 0.61 to $1.39 \mathrm{~J} / \mathrm{s}$. The energy used in this study shows a relationship that is directly proportional to the drying air temperature. The results of this study are similar to the results of the tapioca drying research using a tray dryer $[21,25]$ and drying carrots using a continuous band dryer [8]

\subsection{Energy efficiency}

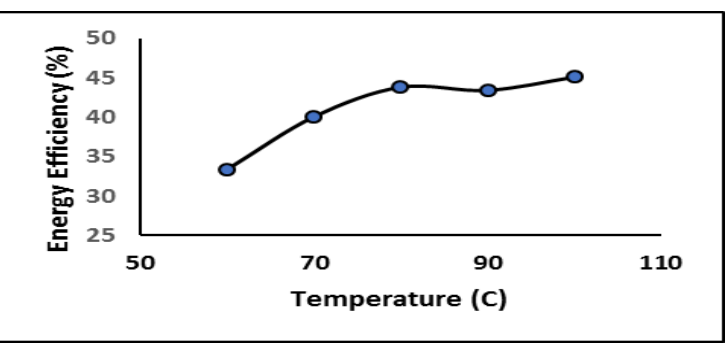

Fig. 7. Effect of dryer air temperature on energy efficiency. 
The effect of increased drying air temperature on energy efficiency is shown in Fig 7. At a temperature increase of $60-100^{\circ} \mathrm{C}$ the energy efficiency to dry the Aren increases from $33.4 \%$ to $45.1 \%$. At energy efficiency, the increased energy use of each temperature causes the efficiency of energy use to dry the Aren increase. The effectiveness of energy use is influenced by the energy used from the available energy. The research [21] and [18] also showed a similar effect between increased drying air temperature and energy efficiency. The same trend is shown by all types of dryers (convective dryers, microwave dryers, vacuum dryers, solar dryers, and dryer joints) that energy efficiency increases with increasing drying air temperature

\subsection{Product Quality Aren}

The quality of Aren flour is determined by the standard requirements for the resulting

Table 1. Results of Quality Analysis of aren flour.

\begin{tabular}{|c|c|c|c|}
\hline Test Criteria & Unit & Requirement & Test Result \\
\hline Color & - & White * & white. \\
\hline $\begin{array}{c}\text { Water content } \\
\text { (b/b) }\end{array}$ & $\%$ & Maks $13^{*}$ & \pm 10.3 \\
\hline Ash (b/b) & $\%$ & Maks 0.5* & 0.39 \\
\hline Coarse fiber & $\%$ & Maks 0.1* & 0.18 \\
\hline Starch & $\%$ & Min $60 *$ & 60.78 \\
\hline White Degree & - & Min $91 *$ & 92,93 \\
\hline Protein & $\mathrm{b} / \mathrm{b}$ & & 0.49 \\
\hline Fat & $\mathrm{b} / \mathrm{b}$ & & 0.18 \\
\hline
\end{tabular}

*) Indonesian National Standard 01-3724-1995

Table 1 presents the results of the feasibility test of the quality of aren flour. The quality criteria of aren flour seen from the results of the physical analysis (color), proximate analysis (ash content, starch content, protein content, fat content), physicochemical analysis (white degree). The results show that all test criteria have met the quality standards of aren flour as a food ingredient, for crude fiber the results showed still higher than required because of the fibers are still included in the flour because the content of aren flour is very high in which aren flour obtained from tree trunks. Aren flour is made by extracting the tree trunk. Where the flour is taken if the tree is no longer produces nira (aren sugar). The extracted aren flour will be brownish. Based on the degree of white, the white Aren flour is also better quality. The test results indicate that the white degree value of the Aren product has fulfilled the requirement of 92. One of the processing of Aren flour which can cause the difference of ash content value is the starch extraction stage. The minerals contained in the stems can be wasted along with the pulp from the extraction process of aren flour, so that the measured ash content becomes lower, in addition to the amount of fiber contained due to aren tree trunks. The amount of fiber and impurities affect the quality of sugar palm. The more fiber and impurities it contains, the lower the quality. The test results showed that the level of more palm fiber by 0.18

\section{CONCLUSION}

The result of Aren flour proximate analysis used in drying research using pneumatic dryer showed that aren tress has starch content $60.78 \%$, whiteness $92.93 \%$, fiber content 0.18 . The energy analysis of the drying process shows that (i) the energy usage increases with increasing temperature. The energy efficiency increases from 33.4$45.1 \%$, (ii) the higher the temperature followed lower the moisture content. The lowest moisture content is obtained at a temperature of $100^{\circ} \mathrm{C}$ with water content of $10.3 \%$ (iii) the speed of the air flow rate is very important because if it is too low, can be lifted by the airflow, if the flow of airspeed is too high will cause the hot contact between dry air and the material will become too short (iv) the higher the temperature the increased energy utilization

\section{References}

1. M. Lempang, Info Tek. EBONI, 9, 37-54, (2012)

2. Purnawan, J. Tekno. Technoscientia, 4, 28-36, (2011)

3. S. Suherman, M. Djaeni, D. H. Wardhani, and A. C. Kumoro, CSAFS Conf. Proceedings. 430438, (2017)

4. I. Borde and A. Levy, "Pneumatic and Flash Drying," (2006)

5. L. R. Dragiša Tolmač, Zvonimir Blagojević , Slavica Prvulović, Jasna Tolmač, J., Mech. Eng., 8, 89-96, (2010)

6. S. Suherman, A. C. Kumoro, T. D. Kusworo, and N. Hidayati, Adv. Sci. Lett., 23, 56505652, (2017)

7. J. Baeyens, D. Van Gauwbergen, and I. Vinckier, J. Powder Technol., 83, 139-148, (1995)

8. M. Aghbashlo, M. H. Kianmehr, and A. Arabhosseini, J. Food Eng., 91, 99-108, (2009) 
9. S. M. El-behery, W. A. El-askary, M. H. Hamed, and K. A. Ibrahim, J. Comput. Fluids, 68, 159167, (2012)

10. S. Suherman and R. Trisnaningtyas, AIP Conf. Proc., 1699, 2015 (2015)

11. M. Aghbashlo, H. Mohammad, and H. Samimiakhijahani, J. Energy Convers. Manag. 49, 2865-2871, (2008)

12. A. M. E. Tsotsas., Modern Drying Technologi. (2012)

13. N. Colak and A. Hepbasli, " J. Food Eng., 80, 1188-1193, (2007)

14. A. V. Otoniel Corzo, Nelson Bracho and A. P. 'squez, J. Food Eng., 86, 151-161, (2008)

15. S. Suherman, A. C. Kumoro, and T. D. Kusworo, Int. Conf. Chem. Mater. Eng, 050001$1-050001-6,(2015)$

16. A. Akbulut and A. Durmus, J. Energy, 35, 17541763, (2010)

17. İ. Karagüzel, E. Tekİn, and A. Topuz, ,J. Sci. Res. Essays, 7, 3961-3973,(2012)

18. M. R. Assari, H. B. Tabrizi, and E. Najafpour, Int. J. Therm. Sci., vol. 64, 213-219, (2013)

19. A. Fudholi, K. Sopian, M. Y. Othman, and M. H. Ruslan, Energy Build., 68, 121-129, (2014)

20. S. Suherman and Rona., J. Reaktor, 16, 24-31, (2016)

21. N. A. Aviara, L. N. Onuoha, O. E. Falola, and J. C. Igbeka, J. Energy. 73, 809-817, (2014)

22. J. N. W. K, N. Bintoro, and J. T., Pros. Semin. Nas. Perteta, 97-104, (2012)

23. S. J. Temple, S. T. Tambala, and A. J. B. Van Boxtel, J. Control Eng. Prctice. 8,165-173, (2000)

24. C. Nimmol and S. Devahastin, J. Appl. Therm. Eng., 30, 2204-2212, (2010)

25. N. A. Aviara, J. C. Igbeka, and L. M. Nwokocha, J. Int Agrophys, 24, 219-225, (2010)

26. M. Djaeni, N. Asiah, S. Suherman, A. Sutanto, and A. Nurhasanah, J. Renew. Energy Dev., 4, 20-24, (2015) 